\title{
An Analysis of Ouyang Xiu's Economic Thoughts
}

\author{
Jianfei Yang ${ }^{1, a, *, \text { Kun Huang }}{ }^{\text {2, b }}$ \\ ${ }^{1}$ School of Economic Management, Northwest University, Xi’an, China \\ ${ }^{2}$ School of Economic Management, Northwest University, Xi’an, China \\ aRenliyang126@sina.com, b1515975370@qq.com \\ *corresponding author
}

Keywords: Ouyang Xiu, Economic Thoughts, Reform

\begin{abstract}
As one of the eight famous writers of the Tang and Song Dynasties, Ouyang Xiu's literary works was well known by people. It is relished by people that "The drinker's focus on the mountain and rivers instead of wine", "The heavy mountain is at the end of the flat glass and pedestrians are still outside the heavy mountain.” In fact, as a politician, Ou Yangxiu played a certain role in the political arena in the middle of the Northern Song Dynasty besides as a litterateur. His economic thoughts also contributed to the economic development of the Northern Song Dynasty. This article analysis Ouyang Xiu's the thoughts of sharing with the merchant, the land thoughts, finance and currency, the thoughts of national defense economy based on existing literature. Therefore thinking the problem and suggesting of the reform of state-owned enterprise, land farming, tax reforming, Strategic transformation of national defense economy at present.
\end{abstract}

\section{Literature Review}

As a famous literature, thinker, politician of the Middle of the Northern Song Dynasty, Ouyang Xiu's thoughts was studied by later generations. It not only plays an important role in understanding Ouyang xiu's state of mind and literary attainments, but also helps to understand the historical environment in the middle of the Northern Song Dynasty. But looking at the relevant literature, we find that $\mathrm{Ou}$ Yangxiu's thoughts are mainly studied in literature, Confucian classics and the influence of the ideology and culture of the Northern Song Dynasty on Ou Yangxiu's literary theory. [3]There is a little of Ouyang Xiu's economic thoughts. The study of Ou Yangxiu's economic thoughts includes the following articles and several works mentioned. In the article on "Ou Yangxiu's economic thoughts”, Tan min summed up Ou Yangxiu's economic thoughts included the thoughts of sharing with the merchant about guiding the businessman as the best policy but controlling the businessman as the bad policy, the thoughts of land and currency, finance and so on. [6]In the article of researching on Ou Yangxiu's economic thoughts, Tie Aihua analyzes the causes and characteristics of Ou Yangxiu's economic reform thought, the thought of agricultural economic development, the thought of industrial and commercial development, the understanding of finance and currency and other aspects. In the article on "New exploration of Ou Yangxiu's economic thought”, Zhang Shoujun expounded Ou Yangxiu's basic economic viewpoint and analyzed the Ouyang Xiu's carefully reform measures included reducing the burden of farmers, promoting the circulation of commodities and eliminating extravagant corruption.[2] In the article on" Ou Yangxiu's thought of national defense economy", Kong Xiangzhen analyzed Ou Yangxiu's thoughts about the relationship between national defense and economy, the advise relation to the national defense economy. Finally, the author evaluated Ouyang Xiu's national defense economy thoughts. In the article on "The view of making the best of the ground in the economic thought of Ouyang Xiu”, Kong Xiangzhen discussed the disadvantages of harming agriculture and Ouyang Xiu's advise. In the article on "The view of using businessman in the economic thought of Ouyang Xiu”, Kong Xiangzhen analyzed the historical origin and the reason of that time about using businessman, the concrete content of using businessman, the enlightenment to the present. In the article on "The view of dredging the river course in the economic thought of Ouyang Xiu”, he analyzed that how 
the opinion of dredging the river course formed. To addition, he also analyzed it's concrete content. [7]In the book on “Ouyang Xiu's comment”, Huang Jinde analyzed his thoughts included paying attention to agricultural production, measuring the land and averaging tax, storing the farming system, suggesting using businessman. [13]In the book "The history of ancient Chinese economic thought", Ye Shichang analyzed Ou Yangxiu's understanding of economic reform about farming first, hardworking and saving, conducting financial transactions. In summary, most of the literature research on Ou Yangxiu's economic thought involves the idea of Ou Yangxiu's economic thought. Only one or two articles are related to the characteristics and reasons of Ou Yangxiu's economic thought and the practical significance to the development of contemporary society. Based on the understanding of Ou Yangxiu's economic thought, this article tries to analyze the practical significance of Ou Yangxiu's economic thought to contemporary socialist construction.

\section{The main content of Ou Yangxiu's thought of economic reform}

\subsection{Suggesting using businessman.}

Ou Yangxiu mentioned that there are more and more means to gain the interests of the state. The means of pursuing the interests of the merger are becoming more and more ingenious and the merchants among them have a great influence on the interests of the country. There is no other reason except that businessmen get more benefits. If the big businessman get more benefits, they will cooperate with the next small traders to get more benefits. Then the flow of goods will be smooth without blocking. Ou Yangxiu analyses that if the state is competing with merchants for profit and then carry out the monopoly system of salt and wine tea and other things, the state can only gain 3/10 profit. If the state works with businessmen, it can gain half profit. As for how to reduce commodity storage to control commodity prices, Ou Yangxiu proposed that the state should take coercive measures to dump goods stored by merchants into the market, thereby restricting the monopoly of large merchants. [1]Although the profits are small, goods circulate fast and then they can't stagnant. A large country envy the great businessman and fight for profits with them although it has endless goods. It would rather stagnant the goods and cause them corruption. Why? Therefore, the big businessman is good at taking a certain means. They can cooperate with small traders at the expense of losing a little interests. A large country who is good at taking a certain means can cooperate with the great businessman at the expense of losing a little interests. This is to gain more benefits from losing profits by sharing profits with businessmen.[5]

\subsection{The land thoughts.}

At first, Land annexation is very serious because the two tax law that the state levy taxes according to the number of fields in the middle of the Northern Song Dynasty. But land acquisition makes powerful landlords own large amounts of land. They should pay more taxes according to the national tax law. But they colluded with government officials. Instead of paying taxes, they transfer taxes to poor people who own a small amount of land or even no land. They make farmers bear heavy. Ou Yangxiu has always attached importance to the people's livelihood and observed the sufferings of the folk. In view of this situation, he proposed to measure private land according to the grave fault between the amount of land and the tax revenue. That is "measuring the land and averaging tax". However, this law is obstructed because that it damage the interests of landlords with a large number of land. Secondly, many fields were not effectively cultivated because that many officials in the Northern Song Dynasty did not pay much attention to agricultural production. When Ou Yangxiu went to visit during Qingli at Song Renzong period, he found the trouble in Hedong area is that the officials strictly prohibited people from cultivating land along the border so people bought grain from the Liao state as a storage. This practice of strictly prohibit the cultivation of the border areas of song and Liao made Song dependent on buying grain from the Liao Dynasty. Once the Liao state stopped selling grain to the border of Song, the situation was critical. He said, "Now there are twenty thousand or thirty thousand hectares of land in the east of the river. If they are cultivated, three or five million stone grain can be harvested every year." There are many 
deserted land from the west of the capital. No one farmed was not because the land is poor. Only because the peasants have fled because of the heavy tax. There are many abandoned wasteland in the country. [8]Ou Yangxiu advocate that farmers culture the wasteland. People plowing wastelands enjoy exemption from tax. So land has been cultivated to achieve "as much as possible". The problem of superfluous troops has been plaguing the whole of the Northern Song Dynasty. Ouyang Xiu put forward the problem of a large number of troops with the low quality of the army. These people do nothing to defend the country. However they consume much state finance. As for, he said: "now if these idle soldiers are allowed to cultivate land and the state loan will provide seeds. Recruiting people who are familiar with the fields of land as the land official. Using incentives to guide them. So there are many more people willing to farm the fields. For a man, a field can be cultivated. So let forty thousand or fifty thousand people go to farm, then abandoned farmland for a long time can earn several times profits.” This idea of Ou Yangxiu has made the best use of all talents. It can be said that there are two birds with one stone. It not only solve the huge problem of national financial expenditure, but also make the land to be cultivated to the maximum extent.

\subsection{The finance and currency thoughts.}

In terms of finance, Ou Yangxiu adheres to the principle of "make both ends meet". He oppose the Levy of taxes to the people according to the needs of the state and do not consider the need for democracy only for the state. Ou Yangxiu pointed out that there was a lack of fairness in taxation. The three or four class families who work hard bear heavy tax services. But the upper class families with more wealth are exempt from the tax service. He strongly advocate tax equalization, restraining mergers, changing the unfairness of tax service. In terms of money, Ou Yangxiu first recognized the state's profit of casting iron money and then raised objections to the state's casting iron money. He said, "it is not worth to destroy the original rulers of copper coins for the sake of one hundred thousand iron coins every year". In addition, the cast iron money not only undermines the circulation order of copper money but also causes the spread of private iron money.[14] Eventually it makes the iron money more and more devalued and the devalued iron money also causes inflation. Judging from the consequences of casting iron money, people who earn money are privately cast iron. The interests of the state and ordinary people will only be impaired because of currency depreciation and rising prices. Ou Yangxiu also found that the iron coins made by the government at that time were not worth enough. The insufficient value of iron money would also cause the above problems.

\subsection{The national defense economic thought.}

The thought of national defense economy is less involved in previous thinkers. It is a relatively new economic thought in Ou Yangxiu's economic thoughts. Northern Song where Ouyang Xiu lived was often harassed by the Liao and Xixia. Ou Yangxiu not only noticed that the strength of the military power was the key to winning the victory, but the strengthening of the economic strength was an indispensable and important factor. Thus, the national defense economic thought was advanced. In his national defense economic thought, Ouyang Xiu puts forward measures and suggestions on specific national defense economic measures. He put forward four suggestions. The first one is reforming the "military academy" and "state horse" system. The role of "military academy" is to produce and provide weapons. The role of "state horse" in supervising livestock is to manage the breeding grounds of war horses. The "military academy" is only set up in the place at the period of Song Renzong. The quality of ordnance provided by local "military academy" production is not high which limits the improvement of combat effectiveness in combat. Therefore, Ou Yangxiu suggests that the local "military academy" be rectified and the national "military academy" is established so as to ensure the quality of weapons and enhance combat effectiveness.[4] As for "state horse", he appoint officials to the court according to the problem of so many old places in the custody of livestock, not clear boundary, the indulge in corrupt practices. The second one is opening border farming. The third one is carrying out storing the farming system. Ou Yangxiu's land thought has been discussed before. The forth one is developing traffic and transportation at the border so as to improving transport conditions. Ou Yangxiu mentions water transport in the 
measures he writes to the emperor against Xixia. Ou Yangxiu points out that the capital of the Northern Song Dynasty was located in the Bian Jing. Bian Jing was far away from the West and the transportation was inaccessible. So people think that all the materials and forces in the other places could not reach the West. In the Qin, Han, Sui and Tang Dynasties, the capital was located in Yongcheng which was closer to the west. And the transportation facilities were better than the Northern Song Dynasty. He also illustrates the history that Liu Yan built the river course to prove the importance of building the river course. He points out that the grain of Jianghuai can be transported to the west after building the river course. so that the grain in the west is more than enough to provide material reserves against the invasion of Xixia.

\section{The practical significance of Ou Yangxiu's thought of economic reform}

In Ou Yangxiu's economic thought, sharing interests with businessman that is the change of the official camp for the private joint venture is similar to the relationship between the contemporary state-owned enterprises, the private enterprises and the mixed ownership enterprises. The idea of sharing the profits with the merchants has a certain reference to the reform of the contemporary state-owned enterprises. Ou Yangxiu advocated the abolition of the state's prohibition of tea and other commodities, the cooperation between the state and the merchant, the tea salt and other commodities in the sale of large merchants. And then the state and merchants all gain benefits. Today, state-owned capital is more and more inclined to invest in the field of national economy and people's livelihood. The state-owned capital is rarely able to monopolize the operation of a certain industry. The participation of private capital is needed to enhance the vitality of the capital operation.[10] At present, the reform of state-owned enterprises is still in progress. The reform of state-owned enterprises should not only reform the problems of their own existence, but also take into account the cooperation interests of state-owned enterprises and private enterprises. [9] It is a direction for the reform of state-owned enterprises that how to full play private capital's enthusiasm. Ou Yangxiu's land thought shows great importance to agriculture. At present, agriculture is still the foundation of social development in China. However, many rural labor force flee to cities to work and rural land appears deserted with the change of social situation. How to encourage farmers to cultivate deserted land and reduce the loss of labor can also be used for reference from Ou Yangxiu's land thoughts. For example, farmers who cultivate wasteland can provide farm subsidies. Although this measure has been implemented, subsidies are not enough enough to mobilize the enthusiasm of farmers. So we need to improve at this aspect. Using land should be transformed from extensive to intensive to improve the utilization of land and yield per unit land area, to reduce the idle and waste of land according to the requirements of "two fundamental changes" in China's current land policy. In Ou Yangxiu's financial thought, he emphasized the problem of unfair tax burden and urged the average tax. In China's current tax system, although there is tax burden unfair phenomenon, the tax will not be completely fair. So our country is also trying to reduce the unfair phenomenon of tax.[11] The main problem at present is the excessive income gap. How to reduce the income gap by tax, reform the business tax, the value-added tax, the individual income tax, study tax environment is the direction of work hard. In addition, China is in the key stage of deepening the reform in an all-round way. The reform of the tax system is also an important link in the comprehensive deepening of the reform. The goal of the comprehensive deepening of the reform may be realized only the reforms in all aspects cooperate with each other. Ou Yangxiu's defense economic thought shows the relationship between national defense and economy, emphasizing the importance of national defense and economy. They are inseparable. The nineteen major reports of China clearly point out that we must stick to the road of strengthening the army with Chinese characteristics and comprehensively promote the modernization of national defense and the armed forces. At present, there are some problems such as the investment in defense funds, the irrational structure of national defense economy and the matching of personnel training in defense economy in China. [12]In order to cope with these problems, the strategic transformation of national defense economy is imperative. It is necessary to change the concept of national defense investment, coordinate the relationship between the elements of national defense economic structure 
and train the personnel of national defense economy.

\section{References}

[1] Tie Aihua. Research on Ouyang Xiu's Economic Thought [D]. Northwest Normal University, 2003.

[2] Zhang Shoujun. A New Exploration of Ouyang Xiu's Economic Thought [J].Journal of Nanchang University (Social Science Edition), 1996(03):69-74.

[3] Kong Xiangzhen. On the Historical Status of Ouyang Xiu's Economic Thoughts [J].Modern Finance and Economics-Journal of Tianjin University of Finance and Economics, 1993(04):47-52.

[4] Kong Xiangzhen. On Ouyang Xiu's National Defense Economic Thought [J].Modern Finance and Economics-Journal of Tianjin University of Finance and Economics, 1989(06):51-55.

[5] Kong Xiangzhen. The view of dredging the river course in the economic thought of Ouyang Xiu [J].Modern Finance and Economics-Journal of Tianjin University of Finance and Economics,1985(02):30-35.

[6] Tan Min. The Economic Thought of Ouyang Xiu[J].Finance and Economics Research, 1984(06):70-73.

[7] Kong Xiangzhen. On the Proposition of "dredging the river course” in Ouyang Xiu's Economic Thoughts [J].Modern Finance and Economics-Journal of Tianjin University of Finance and Economics, 1984(02):46-49+45

[8] Kong Xiangzhen. The view of making the best of the ground in the economic thought of Ouyang Xiu [J].Modern Finance and Economics-Journal of Tianjin University of Finance and Economics,1983(04):38-44.

[9] Liu Bin. History, Reflection and Trend of State-owned Enterprise Reform [J].Market Research, 2016(09):60-61.

[10] Zhao Shiping. Thoughts on the Reform of State-owned Enterprises in China [J].Trade Practice, 2017(07):82-83.

[11] Chen Lingling, Ren Ningning. Thoughts on the Reform of China's Tax System [J].Modern Economic Information, 2013(09):7-8.

[12] Wu Qingqing. Main Performances and Countermeasures of China's National Defense Economic Strategy Transformation [J].China International Finance (English), 2018(03):192-193.

[13] Huang Jinde. Ouyang Xiu's biography [M]. Nanjing: Nanjing University Press, 1998.

[14] Sun Wenxue. History of Chinese Financial Thoughts (Volume 1) [M]. Shanghai: Shanghai University of Finance and Economics Press, 2008. 